\title{
An integrated approach to ensuring sustainable development of territories
}

\author{
Irina Taranova, ${ }^{1, *}$, Valentina Ivashova $^{2}$, Anastasia Chaplitskaya ${ }^{3}$, Julia Gunko $^{4}$, Marina Ponomarenko ${ }^{5}$. \\ 1 Doctor of Economics, Professor, Financial Management and Banking Department, Stavropol State Agrarian University, 355017, \\ Stavropol, Russia \\ ${ }^{2}$ Candidate of Social Sciences, Docent, Project Management Department, Stavropol State Agrarian University, 355017, Stavropol, \\ Russia \\ ${ }^{3}$ External PhD, Agricultural Economics and Rural Policy Department, Wageningen University and Research, Wageningen, The \\ Netherlands; Senior lecturer, Foreign Languages and International Communication Department, Stavropol State Agrarian University, \\ 355017, Stavropol, Russia \\ ${ }^{4}$ Candidate of Economic Sciences, Senior lecturer, Economic Theory and Agro-Industrial Economy Department, 355017, Stavropol \\ State Agrarian University, Stavropol, Russia \\ ${ }^{5}$ Candidate of Economic Sciences, Associate Professor, Economic Theory and Agro-Industrial Economy Department, 355017, Stavropol \\ State Agrarian University, Stavropol, Russia
}

\begin{abstract}
The article considers modern approaches to ensuring sustainable development of territories. The analysis of publications that set out best practices for harmonizing the socio-economic processes of several regions of the world is carried out. In general, they ensure the satisfaction of the population needs of different localization territories, has been carried out. The empirical part of the study shows the opinion of the regional community of the South of Russia with respect to the possibilities of implementing various approaches to ensure the balanced development of the strategically important territory of Russia. The role of developing regional brands, including rural tourism, for the sustainable development of the Stavropol Territory and improving the quality of life of the population is determined. The competitive potential of the Stavropol Territory, according to the expert community, is focused on the production of grain crops. On the second place are the resort and sanatorium services and opportunities for the development of rural and ethnic tourism. Not enough attention is given to the development of organic food production.
\end{abstract}

\section{Introduction}

The modern interpretation of sustainable development of territories is a process of socio-economic transformations where the primary purpose is a stable, progressive increase in the quality of life of the population of the territories. This is by ensuring the consistency of a combination of crucial factors like: investment policy, natural potential, scientific and technological achievements, human capital and institutional mechanisms used in the regulation of the vectors of development of the territory.

The issue of the practical implementation of an integrated approach in ensuring the sustainable development of territories is becoming relevant.

\section{Literature review}

The topic of sustainable development of territories is relevant in the scientific discussion of modern authors.

Thus, studies of scientists Voinova N., Arcibashev D., Aliushin R., Malina V., the results of which are presented in the article "Interaction of agricultural and ethnographic tourism for the development of Russian regions", based on strategic analysis prove the high potential ensuring the sustainability of Russian territories based on the creation of tourist clusters. The analysis of the study, based on a comprehensive study, emphasizes the possibilities of socio-economic development of rural areas. The study shows that it is advisable to use places known for traditional folk crafts in combination with rural tourism $[1,2]$.

At the same time, an additional influx of the population, usually of a seasonal nature, can cause negative consequences for the territories: an increase in the volume of household waste, a deterioration of the environmental situation, an increase in the transport and anthropogenic load, and in the worst-case scenario, a deterioration in the structure and composition of soils, degradation or destruction of the traditional flora and fauna. All this requires a balanced, integrated approach to the organization of rural and ethnic tourism $[3,4,5]$.

Several studies emphasize that modern innovations in various stages of life carry a definite potential for the socio-economic development of the territory $[6,7,8]$. Also, cities, as the most actively technologically 
developing systems, can become locomotives of sustainable development and adjacent rural territories [9, $10,11,12]$. This can be ensured by an integrated approach in the regional strategic programs.

Spatial planning and master plans are essential tools for sustainable development and land stability. Michalka L. and Kovac B. [13] analyzed deficiencies in the regulatory framework for the balanced development of territories using modern spatial planning practices in Slovakia as examples. They touch upon an important indicator, quality of life, impacting the sustainable development. Creating stability of the socio-economic system is considered an essential goal of spatial planning of the territory. This is emphasized in many studies $[14$, $15]$.

Regional development is closely related to the competitive advantages of territories that affect the competitiveness of the region as a whole. The concept of regional inequality means that there are differences in the economic, social and environmental levels of the regions [16]. According to the author there is a clustered approach to ensure the stability of the socio-economic development of territories, gaining popularity and is becoming dominant in the economic development strategies of the countries in the European Union.

Thus, a review of scientific publications pinpoints the focus of the discussion around the problems of sustainable development of territories in subject areas of balanced economic stability, social and environmental spheres.

\section{Methods and material}

Research methods are the analysis of scientific publications on sustainable development of territories. As well as the results of an expert survey of education, health, agriculture, and local self-government workers conducted in the settlements of the Stavropol Territory represented by zones - central, north-western, eastern and Caucasian Mineral Waters in 2018. In total, 198 people took part in this survey - also, an additional questionnaire among residents of Stavropol was issued. In total, 812 people took part in it.

\section{Results}

The competitive advantages of the territories should become their focus points to achieve growth. This will ensure an increase in the intangible assets as well as, increasing its socio-economic potential.

A distinctive feature of the economy of the modern information society is the increasing role of "intangible assets", "intellectual property", "trademarks", "branding" and "brand management".

Brands are turning into a powerful weapon of competition, a tool for building a business reputation and building consumer confidence and resilience. They express the vision of the company and symbolize the corporate potential created by the entire organization and the region as a whole.
In the context of the current socio-economic development level of the territory, the issue of the occurrence of strong brands, allowing competing in a variety of similar products, provides additional competitive advantages in order to gain or increase consumer confidence.

As part of an expert survey, specialists from enterprises and organizations of the Stavropol Territory expressed their opinion on whether there are special high-quality services, products, and products in the region that can be considered the business card of Stavropol. A third of the participants in the expert survey answered affirmative; almost a quarter answered negative, the remainder could not answer this question. The data are presented in Figure 1 below.

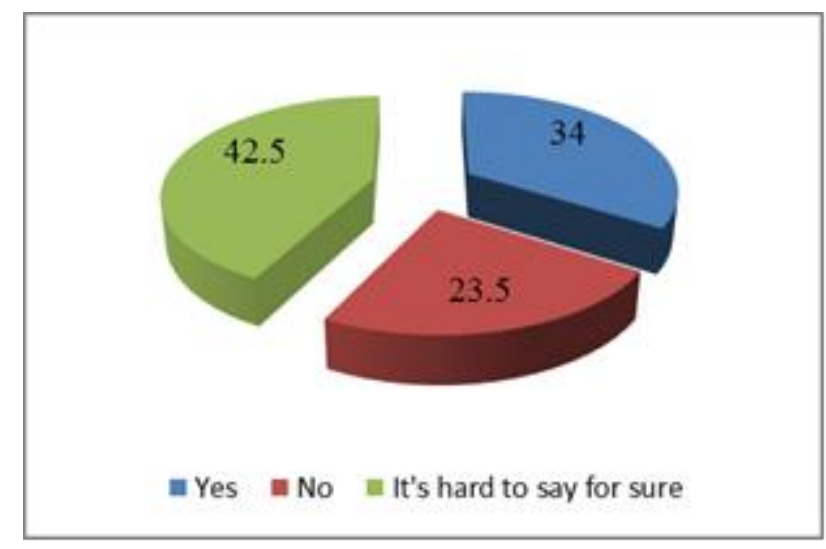

Fig.1. Distribution of answers to the question: "Are there any special high-quality services, products, products in your area that can be considered a business card of Stavropol?"

The next Figure 2 shows what, in the first place, is associated with the Stavropol Territory in expert submissions.

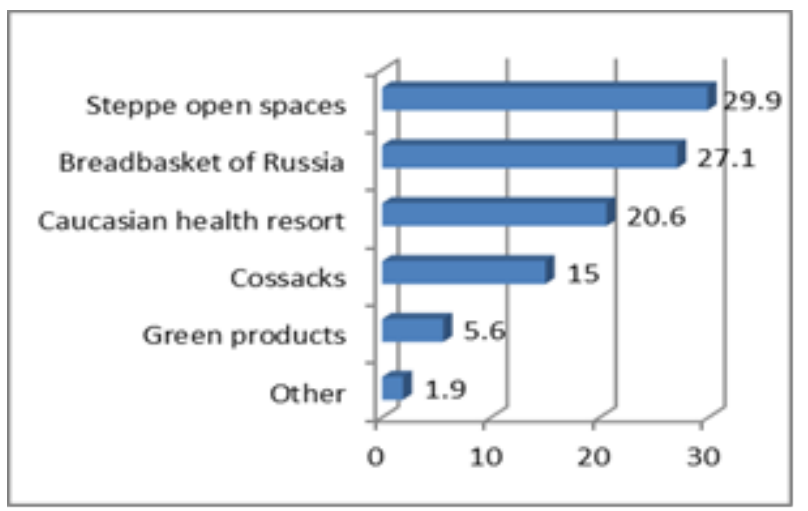

Fig.2. Distribution of answers to the question: "When they say the Stavropol Territory, what are these words primarily associated with?"

Most of the answers of experts include an agrarian theme: $29.9 \%$ of respondents noted the option "steppe expanses", and $27.1 \%$ of the number of respondents said "breadbasket of Russia". The topic of sanatorium and resort services occupies a slightly smaller share in the responses; the option "Caucasian health resort" was noted by $20.6 \%$ of the number of respondents. The topic of the Cossacks came back in $15.0 \%$ of the responses. 
The topic of environmentally friendly products occupied an insignificant share - of 5.6\%.

The result of sustainable development should be the complete satisfaction of the needs of people living in a particular territory and, in general, social well-being and high quality of life.

In the applied aspect, the assessment of the quality of life of the population in a particular territory enables the state and municipal authorities to make information based decisions regarding the improvement of activities in specific areas: education, health, culture, housing and communal services.

A generalizing characteristic of the life quality in the residents' study of the regional centre was the assessment of the comfort of living in this territory. The data are presented in the following table.

Table1. Distribution of answers to the question "How comfortable do you personally live in the city?", \%

\begin{tabular}{|l|l|}
\hline Possible answer & $\%$ \\
\hline 1.Very comfortable not & 35,8 \\
\hline $\begin{array}{l}\text { 2.Rather comfortable than } \\
\text { comfortable }\end{array}$ & 36,9 \\
\hline \begin{tabular}{l} 
3. Average comfortable than \\
\hline $\begin{array}{l}\text { 4.More likely not } \\
\text { comfortable }\end{array}$
\end{tabular} \\
\hline 5. Very uncomfortable & 3,9 \\
\hline
\end{tabular}

Most respondents satisfactorily assess the degree of comfort in a city. $36.9 \%$ believe that they live moderately comfortable, $35.8 \%$ believe that they live more comfortable, $15.9 \%$ live very comfortably in the city, and only $11.4 \%$ live slightly uncomfortable or very uncomfortable.

Table 2. Distribution of answers to the question "Rate the quality of provided services in the city", $\%$

\begin{tabular}{|l|l|}
\hline Possible answer & $\%$ \\
\hline $\begin{array}{l}\text { 1.Very high quality (the quality of the } \\
\text { services provided to you and your family } \\
\text { is absolutely (entirely) satisfied) }\end{array}$ & 5,9 \\
\hline $\begin{array}{l}\text { 2.High quality (the quality of the services } \\
\text { provided to you and your family as a } \\
\text { whole satisfies) }\end{array}$ & 17,9 \\
\hline $\begin{array}{l}\text { 3.Average quality (the quality of the } \\
\text { services provided to you and your family } \\
\text { is partially satisfied (only on specific } \\
\text { issues) }\end{array}$ & 59,3 \\
\hline $\begin{array}{l}\text { 4.Low quality (the quality of the services } \\
\text { provided to you and your family to a } \\
\text { greater extent does not satisfy) }\end{array}$ & 11,4 \\
\hline $\begin{array}{l}\text { 5.Poor quality (the quality of the services } \\
\text { provided to you and your family is not }\end{array}$ & 5,5 \\
satisfactory) & \\
\hline
\end{tabular}

$59.3 \%$ of respondents rated the quality of services provided in the city as average, $23.8 \%$ fully or completely satisfied with the quality of services. $16.9 \%$ rated the quality of services provided in the city as low or very low.
The provided services to residents of the city by health care institutions, culture, and public utilities received a relatively high or average quality rating. Less than $1 / 4$ of respondents consider that the quality of services provided in the city as low or, poor. On average, $10 \%$ of respondents have never used any type of provided service, and therefore, they cannot evaluate the quality of it.

The respondents gave the highest rating to the facilities of culture and leisure. The level of service of cultural centres and cinemas are rated to be of a very high quality of services, $38.1 \%$. The services of museums are rated, at $35.5 \%$. The libraries services are rated $30.8 \%$ as very high, whilst the sport facilities received the lowest rating. Only $25.7 \%$ appreciated the offered services.

Among health services, ranked as a very high quality of services, $28.2 \%$ of respondents rated the work of pharmacies as very low $9.3 \%$ rated ambulance services. The services provided by polyclinics, hospitals, and maternity hospitals were rated as average by respondents.

About $20 \%$ rated the quality of electricity, gas and water supply services as very high, $-37 \%$ of the respondents rated them high and, $28.6 \%$ of the respondents rated the quality of electricity, gas and water supply services as average.

Among the respondents, heat supply services were also recognized as satisfactory.

The condition of the houses and the quality of work of the management company satisfy $35.6 \%$, on average $14.9 \%$ rated the condition of the houses, and the work of the management company as low and about $7.4 \%$ gave a poor rating.

The yard condition and the level of maintaining order at the entrance were also rated by $76 \%$ of respondents as very high, high or medium.

$29.4 \%$ of respondents have never used subsidies for public services. $26.7 \%$ consider the quality of subsidies to be average, $15.5 \%$ as high and only $7.3 \%$ as very high.

Table 3. Distribution of answers to the question "Please rate the activities of municipal authorities to improve the quality of life of people", \%

\begin{tabular}{|c|c|}
\hline Possible answer & $\%$ \\
\hline $\begin{array}{l}\text { 1. Excellent (the authority adequately } \\
\text { copes with the duties assigned to it and } \\
\text { successfully solves the problems that } \\
\text { arose in various spheres of life) }\end{array}$ & 4,7 \\
\hline $\begin{array}{l}\text { 2. Good (the authority as a whole copes } \\
\text { with the duties assigned to it, but still } \\
\text { several unresolved problems remain) }\end{array}$ & 27,7 \\
\hline $\begin{array}{l}\text { 3. Satisfactory (the authorities are doing } \\
\text { something to solve existing problems, but } \\
\text { this, in your opinion, is not enough) }\end{array}$ & 45,5 \\
\hline $\begin{array}{l}\text { 4. Unsatisfactory (in your opinion, the } \\
\text { government does not cope with the duties } \\
\text { assigned to it, although some actions } \\
\text { aimed at solving the problems of citizens } \\
\text { are being taken) }\end{array}$ & 16,8 \\
\hline
\end{tabular}




\section{Bad (power does not work at all)}

5,3

$45.5 \%$ of respondents rated the activity of municipal authorities to improve the quality of life of people as satisfactory, $27.7 \%$ - as good, $4.7 \%$ - as excellent. $22.1 \%$ of respondents believe that the government is not coping with its assigned responsibilities, although some actions are being taken, or believe that the government does not work at all.

Table 4. Distribution of answers to the question "Please indicate which problems, in your opinion, should the city administration focus on?" \%

\begin{tabular}{|l|l|}
\hline Possible answer & $\%$ \\
\hline 1. Social targeted programs & 19,2 \\
\hline 2. City improvement & 39,4 \\
\hline 3. The content of municipal housing & 28,7 \\
\hline 4. Public transport & 41,0 \\
\hline 5. Road maintenance & 53,3 \\
\hline 6. State of the industry & 17,1 \\
\hline 7. The problem of children and youth & 49,0 \\
\hline 8. Public order protection & 36,7 \\
\hline 9. Medical care & 49,1 \\
\hline 10. Housing and communal services & 40,1 \\
\hline 11. Preschool and school education & 29,2 \\
\hline 12. Ecology & 36,7 \\
\hline 13. Another option & 3,1 \\
\hline
\end{tabular}

$53.3 \%$ of respondents believe that first of all; it is necessary to pay attention to the maintenance of roads. In second place is the problem of children and youth (49.0\% of respondents) as well as medical services (49.1\% of respondents).

Very significant problems that should be addressed, according to the respondents, are public transport, housing and housing and communal services, city improvement, ecology, public order protection, preschool and school education, maintenance of municipal housing.

\section{Discussion and conclusions}

Thus, on the basis of a theoretical understanding of the problem of sustainable development of the territory, attraction of empirical materials to study the socioeconomic potential of the Stavropol Territory, and satisfaction with the quality of life of the population of the regional capital, one can identify critical points to ensure stability: integrated infrastructure development of the territory; mobilization of the socio-economic potential of rural and ethnic tourism; development of organic food production; addressing environmental safety issues; introduction of system tools for managing sustainable development of the territory.

\section{References}

1. N. Voinova, D. Arcibashev, R. Aliushin, V. Malina, Journal of Cultural Heritage Management and Sustainable Development 9(2), 247-262 (2019)

2. V. Okrepilov, S. Kuzmina, S. Kuznetsov, I.O.P. Conference Series: Materials Science and Engineering 497(1) (2019)

3. L. Albornoz-Mendoza, A.J. Mainar-Causapé, Papers in Regional Science 98(2), 1215-1238 (2019)

4. M. Jouini, J. Burte, Y. Biard, H. Amara, C. Sinfort, Science of the Total Environment 655, 1017-1027 (2019)

5. R.A. Castanho, J.M.N. Gómez, J. Kurowska-Pysz, Sustainability 11(5), 1354 (2019)

6. A. Maizza, M. Fait, P. Scorrano, A. Iazzi, Sustainability 11(4), 952 (2019)

7. I. S. Baklanov, O. A. Baklanova, A. M. Erokhin, N. N. Ponarina, G.A. Akopyan TarihKültürveSanatAraştırmaları T. 7- 2, 41-47 (2018)

8. V. Ivashova, V. Goncharov, A. Erokhin, O. Kolosova, V. Berkovsky, International Journal of Civil Engineering and Technology T. 9 13. 398-404 (2018)

9. M.V. Pastukhova, L.G. Pastukhova, I.O.P. Conference Series: Materials Science and Engineering, 481(1) (2019)

10. D.G. Rocha, V.P Alexandre Weiss, Health Promotion International 34, I46-I55 (2019)

11. I. Viola, I.P Borrelli, R. Misso, G.P. Cesaretti, Quality - Access to Success 20(S2), 650-657

12. K. Laschefski, Sustainable Cities and Society 45,159-171(2019)

13. L. Michalka, B. Kovac, I.O.P. Conference Series: Materials Science and Engineering 471(9), (2019)

14. W. Leal Filho, S.K. Tripathi, J.B.S.O.D. Andrade Guerra, V. OrlovicLovren, J. Willats, International Journal of Sustainable Development and World Ecology 26(2), 179-190 (2019)

15. T. Berchoux, C.W. Hutton, Applied Geography 103, 98-111(2019)

16. K. Rentkova, I.O.P. Conference Series: Materials Science and Engineering 471(10), (2019) 